\title{
Elementos para uma Cartografia da Fé: Usos Religiosos do Espaço Urbano e Interpelação da Laicidade'
}

\author{
Elements for a Cartography of Faith: \\ Religious Uses of Urban Space and the Interpellation of laicity
}

Júlia Miranda

RESUMO

\begin{abstract}
O traçado de uma cartografia da fé pelos usos religiosos do espaço urbano em Fortaleza é o que se quis mostrar. Esse "mapa invisível" da cidade resulta das práticas de grupos católicos nas últimas três décadas. Entre elas principalmente a construção de edificações, a instituição de alternativas aos tradicionais espaços de vivência da fé e a apropriação permanente e temporária de ruas e logradouros públicos. São maneiras novas de "praticar a cidade", cujas implicações são aqui analisadas. A novidade na ação dos católicos contemplados na pesquisa empírica que dá base às reflexões consiste principalmente na reelaboração das práticas, acompanhada da ressignificação de antigos símbolos e das reinterpretações da tradição. $\bigcirc$ que há de particular na cidade de Fortaleza? O texto vai mostrar. Esses usos religiosos do espaço urbano trazem elementos novos à discussão sobre a laicidade ou, dito de forma mais abrangente, sobre o lugar da religião no espaço público assim como ajudam a entender as novas sociabilidades que se vão instituindo nos marcos dessas transformações.
\end{abstract}

PALAVRAS-CHAVE: Religião e Espaço Público; Usos Religiosos da Cidade; Cartografia da Fé.

ABSTRACT

The drawing of a map of faith as shaped by religious uses of the urban space in Fortaleza is what is intended to be shown here. This "invisible map" of the city is an upshot from practices of Catholic groups in the past three decades. Among those practices one can highlight chiefly the construction of buildings, the creation of alternatives to traditional worship spaces and permanent and temporary appropriation of public streets and parks. They are new ways to "seize the town", the implications of which are discussed in this paper. The new aspects of the action of Catholics who are surveyed in the empirical research that underpins the study consist mainly of reworked practices, together with the reinterpretation of ancient symbols and traditions. What's particular in the city of Fortaleza? The text will show. These religious uses of urban space bring forth new elements to the discussion on secularism or, put more broadly, on the role of religion in public spaces, while at the same helping understand new social arrangements that will go on establishing the milestones of these transformations.

KEYWORDS: Religion and Public Space; Religious Uses of the City; Mapping of Religious Areas of the Faithful.

\footnotetext{
${ }^{1}$ Recebido em 20/11/2016. Aprovado em 20/01/2017.

2 Professora da Universidade Federal do Ceará. Email: julia.miranda@ outlook.com
} 


\section{Introdução}

Mesmo considerando-se o lugar de destaque conquistado na agenda pública pelas discussões sobre a pertinência do reconhecimento de preceitos religiosos pelos cidadãos, pelos gestores político-administrativos e pelo Poder Judiciário brasileiros nas decisões que dizem respeito a temas de natureza civil, poderia ser um exagero pensar na religião como responsável por novos ordenamentos espaciais das cidades. Não neste início de século XXI quando as estatísticas apontam uma diminuição da religiosidade institucional e o aumento no número dos sem religião entre outros dados que ajudam a pensar sobre as novas configurações do religioso no Brasil. Não numa capital com mais de dois milhões e meio de habitantes (a quinta do país). Entretanto é disso que trata este artigo ao apresentar um conjunto de fatos relativos ao compartilhamento do espaço urbano e refletir sobre eles a partir das práticas de grupos católicos. Aqueles justamente cuja presença pública é mais forte e pode ser observada na política, na educação e no meio artístico entre outros. E igualmente aqueles cujos posicionamentos em muitos casos guardam significativa distância da $\mathrm{CNBB}$, que se mantém, não obstante, a interlocutora principal do poder público com os fiéis católicos.

Nas últimas três décadas, grupos cristãos - de modo particular os católicos - veem transformando a cidade de Fortaleza por meio da construção de edificações, da instituição de alternativas aos tradicionais espaços de vivência da fé, assim como da apropriação permanente e temporária de ruas e logradouros públicos. São maneiras novas de "praticar a cidade", cujas implicações representam o interesse deste trabalho. A novidade na ação dos católicos contemplados na pesquisa empírica que dá base às reflexões ${ }^{3}$ consiste principalmente na reelaboração das práticas, acompanhada da ressignificação de antigos

\footnotetext{
${ }^{3}$ Uma extensiva pesquisa empírica foi realizada em Fortaleza, de 2010 a 2014, tomando como centrais os grupos e comunidades católicos e fazendo um contraponto com as denominações evangélicas que concorrem com as primeiras por visibilidade e presença efetiva na esfera pública. Participaram dela os bolsistas de PIBIC Juliana Sampaio, Aurimar Albuquerque, Emília Morais e Priscila Tavares. Os trabalhos incluíram o acompanhamento de eventos e a realização de etnografias e entrevistas. Farto material fotográfico foi igualmente produzido e integra o acervo do Núcleo de Estudos de Religião, Cultura e Política do PPGS da UFC.
} 
símbolos e das reinterpretações da tradição. Mas é preciso lembrar que sua análise não pode se fazer à margem justamente daqueles elementos que criam as condições de possibilidade para esse processo e que respondem por suas consequências. Que elementos seriam esses? $\bigcirc$ que há de particular na cidade de Fortaleza? Finalmente, há que se perguntar como esses usos religiosos do espaço urbano trazem elementos novos à discussão sobre a laicidade ou, dito de forma mais abrangente, sobre o lugar público da religião nas sociedades de matriz católica hegemônica?

\section{Um olhar situado na convergência disciplinar}

As dificuldades para explicitar "o olhar" assumido neste artigo já começam quando nos deparamos com a especialização do saber das ciências sociais e a consequente impossibilidade de encontrar um nicho disciplinar próprio para um objeto que faz convergirem as reflexões que têm caracterizado a sociologia urbana, a sociologia da religião, a antropologia, a geografia e a história social. Os estudos sobre o tecido urbano têm uma longa e diversificada história acadêmica. Barreira e Mattos (2013, p.531), ao analisarem teses que tratam do tema no PPGS da UFC, distinguem "investigações feitas na cidade" e "investigações feitas sobre a cidade". Esta análise pode ser definida de ambas as formas. Afastamo-nos dos estudos mais frequentes na sociologia urbana - com ou sem o recurso à antropologia e à geografia política - como aqueles interessados no bairro como unidade de análise, os que tratam das relações de segmentos de moradores com o Estado, que focam na construção de lideranças comunitárias ou mesmo dos que enfatizam usos alternativos face às imposições administrativas como assinalados pelas autoras no caso estudado.

Esta análise incide sobre as práticas dos grupos católicos carismáticos - por serem eles os que preenchem os critérios assinalados acima - buscando dar conta dos processos de apropriação da cidade por esses fiéis. Parte-se do pressuposto de que, embora dispersos em distintos bairros, esses católicos apresentam homogeneidade nas suas crenças e práticas o suficiente para que sejam considerados como unidade de análise. E essa uniformidade se acentua no caso da Comunidade Shalom que tem a quase totalidade das iniciativas que resultam nos fatos aqui apresentados e mantém uma negociação de interesses mútuos com 
as instâncias católicas institucionais. A Arquidiocese e seus representantes clericais apostam no poder de arregimentação de fiéis da Comunidade e esta vai ocupando espaços junto à hierarquia local ${ }^{4}$.

Sigo Canclini (2008) quando ele lembra que há algumas décadas caracterizamos o urbano levando em conta também os processos culturais e os imaginários dos que o habitam. Entendo que nenhuma análise abarca a totalidade dos processos urbanos e dos imaginários que ele engendra e que conferem sentidos à cidade. Sentidos que se multiplicam, que convergem e outras vezes se distanciam segundo consideremos diferentes grupos socioculturais.

Para a adoção desta perspectiva de análise muito contribuiu a reflexão de Roger Chartier (2003;1993;1995;1999) sobre a história da leitura como prática cultural. Sua insistência no fato de que o sentido das práticas culturais provêm de uma relação dialógica entre as propostas do texto e as categorias interpretativas de seus consumidores que assim criam e inventam. Os usos do espaço urbano aqui são considerados prática cultural e representam uma maneira particular de "ler" a doutrina católica (neste caso inclusive com o objetivo de seguir as diretrizes da instituição). Dizem respeito aos "consumidores" católicos, clérigos e laicos de diferentes grupos socioeconômicos. Em Fortaleza essas práticas combinam de modo singular as temporalidades e os espaços, deixando traços através dos quais é possível acompanhar "a leitura" feita pelos católicos para significar Fortaleza como "uma cidade de deus"5. Elas vão criando os elementos para um novo traçado, explicitando "um mapa urbano invisível" (Vale:2000) que integra Iugares, circuitos e territórios ${ }^{6}$ num fluxo permanente só perceptível por partes.

"O duplo processo de industrialização e de urbanização perde todo seu sentido se não se concebe a sociedade urbana como objetivo e finalidade da industrialização, se se subordina

\footnotetext{
${ }^{4} \mathrm{Na}$ sua tese de doutorado em elaboração (PPGS/UFC) Emanuel Freitas narra caso emblemático de uma sessão especial na Assembleia Legislativa do Ceará para comemorar o aniversário da Comunidade Shalom e durante a qual o bispo beijou a mão de Moisés Azevedo, fundador da comunidade e sua liderança máxima.

${ }^{5}$ Expressão ouvida de uma entrevistada da comunidade carismática Shalom e que está em acordo com o imaginário religioso da cidade desde as suas origens.

${ }^{6}$ O lugar neste artigo representa o espaço físico onde estão geograficamente construídos templos e imagens podendo ser o bairro. O circuito é a zona geograficamente delimitada que tem por baliza as edificações, cultos e trajetória de caminhadas. Já o território aqui é considerado geograficamente como construção histórica e social permeada por relações de poder, e também antropologicamente como possuindo uma dimensão simbólica que implica processos de subjetivação e identificação daqueles que ao território pertencem. São casos exemplares os territórios "do Nova Assunção" e de "Fátima". Quanto ao termo fluxo ele fala da dinamicidade e variabilidade dos deslocamentos humanos na urbe.
} 
a vida urbana ao crescimento industrial" lembra Lefebvre (2008). Este é o primeiro elemento a ser considerado entre tantos outros que alimentam as polêmicas sobre a planificação do espaço urbano pelas instâncias administrativas, de modo a priorizar as necessidades sociais, necessidades daqueles que habitam a cidade. Assim, o que se impõe como elemento definidor é o direito ao uso pleno de tudo que a vida urbana coloca à disposição dos indivíduos que nela vivem; espaços, serviços e direitos. Mas nem tudo pode ser planejado pelo administrador urbano.

Tal é o caso quando se trata da instituição de condições para as práticas religiosas. Elas se transformam, seguem dinâmicas próprias, vez que já não estão restritas aos templos, dos quais, ao contrário, se distanciam em cada vez mais oportunidades. É possível, acredita-se, acompanhar essas transformações através das novas marcas deixadas no espaço urbano pelos grupos religiosos. Bourdieu (2003) pensou o campo católico como espaço onde os laicos se caracterizavam apenas como consumidores dos bens de salvação mas as recomposições do catolicismo brasileiro os levou a uma prática criativa e inventiva e não mais somente à posição de coadjuvantes do clero na implementação das orientações do Vaticano.

O pensamento marxista, através de Henri Lefebvre (2008), se afasta da vertente althusseriana ao enfatizar, na reflexão sobre a cidade, o lugar dos sujeitos que nela vivem, os processos de decodificação pelo qual são responsáveis no dia-a-dia. Sua perspectiva de análise do espaço urbano se aproxima de Michel de Certeau (1997), para quem os usos, como prática ativa dos consumidores, é que dão forma ao cotidiano das urbes, definindoas funcional e esteticamente. Entre nós, Magnani (2002), ao propor o método etnográfico para uma análise "de perto" e "de dentro" dos fenômenos urbanos segue essa mesma direção e chama a atenção para o fato de os debates sobre as questões relativas à cidade, em sua grande maioria, ignorarem certos atores sociais, tomando as urbes quase como independentes dos que nela vivem. $\bigcirc$ "homem comum" usa a cidade, "pratica-a" seguindo lógicas próprias e deixa traços não identificáveis ao olhar distante e "de fora". Essa é a linha de reflexão aqui seguida. Se "praticar a cidade" é construir alternativamente o comum, de forma singular, lembro que nada é mais comum do que a religiosidade das populações nordestinas. 


\section{Dos números do Censo ao que o Censo não mostra}

Em um país com as dimensões do Brasil é preciso olhar separadamente para cada região pois nelas mudam os números, as práticas e consequentemente as configurações que envolvem o catolicismo assim como as configurações no seu interior. Essas reconfigurações não cabem nos números censitários principalmente quando resultam em peculiaridades como neste caso. Embora o centro político do país seja Brasília e as maiores cidades sejam São Paulo e Rio de Janeiro, elas estão longe de serem representativas numericamente ou em termos de diversidade das práticas católicas ${ }^{7}$. A região onde melhor se explicitam as "metamorfoses" do catolicismo é a Região Nordeste ${ }^{8}$. Ela é a mais católica e como consequência nela os evangélicos representam uma significativa " concorrência " por adeptos e pela presença no espaço público.

Casanova (apud MAFRA, 2013, p. 45] afirma que as relações entre a Igreja Católica e o Estado no Brasil foram marcados pela submissão da primeira até os anos 1960, quando a Igreja Católica conquistou uma posição hegemônica, acolhedora e heterogênea. Particularmente prefiro pensar essas relações como profundamente ambíguas variando em intensidade segundo o momento histórico considerado (Miranda, 1987). De qualquer modo a questão tal como posta por Casanova esconde o fato de que a instituição não apenas acolheu correntes sociais distintas mas viu surgirem em seu seio hermenêuticas e modos de organização católicas diferenciadas.

Fortaleza está dividida em seis Regiões Administrativas que reúnem os bairros da zona costeira Leste e Oeste, o centro e as zonas mais distantes no Sul, Sudeste e Sudoeste. No lado Leste da cidade, os bairros que as integram são majoritariamente considerados pelo IBGE de classes $A$ e B. $O$ centro e adjacências são hoje pouco ou nada residenciais pois a cidade se expandiu para o Leste, seguindo a faixa litorânea principalmente. Atualmente há um processo de "interiorização" no sentido Sul da cidade para onde caminham os projetos residenciais em expansão. No entanto a exemplo de tantas outras capitais brasileiras Fortaleza possui bairros onde se misturam, embora em espaços bem

\footnotetext{
${ }^{7}$ São Paulo e Rio de Janeiro concentram expressivo número de pentecostais e poucos católicos segundo o Censo de 2010.

${ }^{8} \mathrm{Na}$ região Nordeste o número de evangélicos comparado aos católicos aumenta somente nas áreas metropolitanas também segundo os dados do Censo de 2010.
} 
demarcados, mansões e comunidades sob controle de facções criminosas. Também essas particularidades só são assinaladas pelo Censo que não tem como aprofundar as implicações das práticas culturais nesses bairros multifacetados. Em vários bairros de classe média alta, onde predominam as casas, a elevada taxa de violência urbana tem levado as pessoas que neles vivem a um quase completo isolamento: muros muito altos, cercas elétricas ou de arame farpado e vigias. Ninguém conhece os vizinhos e o bairro é percorrido sempre de carro. Já em outros bairros, distantes das regiões Leste, Nordeste e Sudeste, ainda é possível identificar um estilo de vida com resquícios da urbanidade interiorana: partilha entre vizinhos e moradores, uso coletivo e permanente das vias e demais logradouros públicos, etc.

Não se busca aqui aprofundar o conhecimento de nenhum bairro a partir de suas características. Mas esses esclarecimentos são necessários para uma visualização da cidade como lugar de moradia, antes que se passe aos aspectos contemplados, quais sejam: os usos de seus moradores, indistintamente tomados como praticantes do catolicismo carismático. São importantes para a reflexão também os estilos de vida instaurados ou reformados. Para além da antiga e muito forte tradição católica dos fortalezenses esse "novo conjunto de fatos" é um caso "bom para pensar" inclusive quanto às suas implicações nos debates sobre laicidade.

\section{Porque laicidade}

O pluralismo religioso apresenta ao pesquisador da sociologia o desafio de pensar - lugar das religiões no espaço público e o conduz naturalmente à análise das relações entre o Estado e a(s) igreja(s), entre o Estado e os segmentos da população identificados por sua pertença religiosa e reivindicadores de direitos na convivência com outros credos. Um desses direitos diz respeito aos símbolos religiosos. Da sua exposição no espaço público seja peloporte no corpo e nas vestimentas como profissão de fé seja na produção e circulação de ícones destinados ao culto.E Também da dinâmica das práticas que fogem à expressão privada mas que simbolizam igualmente o religioso assim como de sua aposição em edifícios e ambientes de uso plural e secular. Falar dos usos religiosos do espaço urbano é uma forma de se inserir nessa reflexão. 
Uma rápida olhada retrospectiva sobre o debate acadêmico a respeito do pluralismo religioso, da secularização e dos secularismos mostra que ele surge do desejo de entender as sociedades do Ocidente Norte objetivando apreciá-las com base no modelo tradicional de laicidade cujos casos paradigmáticos são a França e os Estados Unidos da América. Diferentes teorias se desenvolveram durante toda a segunda metade do século XX incluindo mesmo um "retorno do religioso " em algumas produções dos anos 1990?. Constatações como a perda da influência institucional da Igreja Católica, o declínio das práticas cultuais ou sua privatização foram constituindo elementos importantes dessas teses servindo-Ihes de base empírica. E sabemos o quanto a separação entre Estado e Igrejas cristãs nessas sociedades forneceu o pressuposto para a análise dos diferentes casos nacionais unificados não obstante pela referencialidade das sociedades francesa e estadunidense.

Sabemos igualmente que o momento atual é marcado pelo desenvolvimento de reflexões que questionam o tradicional « modelo separatista " e vão buscar elementos para pensar em outros termos as relações entre Estado e Igreja e consequentemente a laicidade e o secularismo. Casanova (1994; 2007 e 2009) cujos trabalhos são até aqui considerados um marco nesse desvio teórico vem abrindo espaço para novas possibilidades. Stepan (2011) concebe as diferentes realidades regionais e nacionais nos marcos de " multiple secularism " enquanto Diotallevi (2015) lembra que o modelo separatista que geralmente justifica um certo tipo de relação entre Estado e Igreja como laicidade é hoje uma exceção. Por seu lado, analisando os países da Europa Ocidental Portier (2011) afirma que « a Europa da religião se constrói (tendencialmente) em torno de um sistema de separação flexível, com base no duplo princípio de igualdade e reconhecimento " (p.12). $\bigcirc$ debate se complexifica e de modo geral vai se expandindo a compreensão de que o separatismo no sentido tradicional pode não beneficiar a consolidação dos projetos democráticos de governo (Casanova, 2007). Quanto ao uso das categorias "separatismo radical " e

${ }^{9}$ É o caso da maioria dos artigos publicados na revista Catholicisme et Société Contemporaine, vol.XXII, no.2, outubro de 1990 organizado por Jean-Guy Vaillancourt e publicada em Montréal pela Editora da UnM.

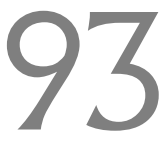


" separatismo moderado " é ainda Diotallevi que lembra seu baixo potencial heurístico pois são variados os casos no interior de cada uma dessas classificações.

Assim, o consenso converge também para a necessidade de se considerar particularidades. No Brasil o debate no que tange aos parâmetros para falar de secularização da sociedade, de desinstitucionalização e de privatização da religião não se iniciou até o final do século XX mas tem originado reflexões ancoradas na nossa história (Miranda, 2013 ; Mariano, 2011 e Montero, 2013 entre outros). Fora do meio acadêmico ele reúne principalmente agentes religiosos nas igrejas e comunidades, nas mídias, nas eleições partidárias e nas práticas de vereadores, de deputados estaduais e federais assim como de senadores representantes estes de variadas denominações evangélicas e católicas. "Secularismo " que Casanova (2009) define como visão de mundo que pode ser utilizado para qualificar uma ideologia ou como princípio de organização do Estado é um termo dificilmente usado e remete a realidades ausentes no espaço público brasileiro, por enquanto.

A natureza relacional do campo religioso no Brasil faz mudarem permanentemente as configurações entre denominações e no seio de cada uma delas. A " concorrência " apoiada sobretudo nos números censitários aparece no questionamento da administração pública e nas posições dos parlamentares eleitos feitos pelas lideranças religiosas e demais fiéis. A busca pelo estabelecimento dos limites razoáveis da cohabitação entre confissões tal como sugerido pelos quebequenses por exemplo (Taylor et Maclure, 2010) continua incipiente entre nós. Não existe ainda no Brasil uma política clara de regulação do religioso. Não há leis que balizem o discurso estatal. A regulação do religioso segue as injunções locais e os projetos municipais e estaduais aprovados no legislativo.

Em Québec, Taylor e Maclure participaram, em 2007, de Comissão instituida pelo governo do Québec para apresentar proposições com vistas aos arranjos que iriam garantir a convivência pacífica entre fiéis de diferentes tradições religiosas. A reflexão desses autores toma a particularidade da sociedade quebequense onde o elemento imigração possui uma centralidade que nos é desconhecida. Mas é preciso lembrar que naquela Província canadense a matriz religiosa fundante e majoritária é o catolicismo, tão presente e ordenador das práticas estatais até os anos 1960 quanto foi o catolicismo brasileiro, mesmo depois da separação entre Estado e Igreja no final do século XIX. Sim,

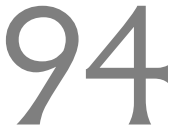


porque é preciso lembrar que a Constituição de 1934 foi em parte fruto da organização e das reivindicações católicas e com elas esteve totalmente afinada.

Trago aqui o caso quebequense porque, a despeito dessas semelhanças com o catolicismo brasileiro, seus analistas sequer cogitam de fatos como aqueles aqui tratados, fatos que aliás não guardam semelhança com as práticas católicas em outras capitais. Destaco aqui aquele que configura justamente a exibição de símbolos religiosos. Os analistas acima citados tratam do porte de símbolos religiosos por agentes do Estado considerando-o incoveniente enquanto que o proselitismo por parte desses agentes seria inadmissível. Quanto aos demais indívíduos esse uso seria livre, desde que observadas especificidades. Lembro que no caso quebequense há uma configuração religiosa diferente e "os concorrentes" (principalmente católicos, muçulmanos, judeus e evangélicos) possuem muito menor identidade de crenças e práticas se comparados ao caso brasileiro. O que dizer então da construção de imagens de Nossa Senhora e de outros santos nas praças públicas e da instituição de um número cada vez maior de caminhadas (antigas procissões) e de eventos de massa fazendo uso de extensas áreas urbanas e de equipamentos culturais e esportivos absolutamente seculares ? "Isso é coisa nossa ".

\section{Um "mapa invisível" de Fortaleza}

A capital do estado do Ceará é a quinta cidade em população do país com mais de dois milhões e meio de habitantes e o quinto colégio eleitoral. Está localizada no litoral Nordeste e possui $314,930 \mathrm{~km}^{2}$ de área, sendo a capital de maior densidade demográfica. É a cidade nordestina com a segunda maior área de influência regional (atrás apenas de Salvador] de acordo com o último Censo, realizado em 2010. O perfil extremamente católico de seus habitantes (como do restante do Ceará) se confirma na classificação como segunda cidade onde essa tradição religiosa é mais forte e na particular distribuição geográfica dos fiéis se comparada a outras capitais.

○ Atlas da Filiação Religiosa e Indicadores Sociais no Brasil, lançado em 2003, embora não se detenha sobre as especificidades regionais ou locais do catolicismo brasileiro do final do séc. $\mathrm{XX}$, destaca que a Região Metropolitana de Fortaleza foge aos 
modelos binário e ternário estabelecidos com base na análise dos micro-dados do censo ${ }^{10}$, apresentando uma estrutura intermediária e caracterizada pela significativa presença de católicos também no centro da Região Metropolitana. É possível ainda observar que, mesmo estando localizada no litoral, Fortaleza permanece fortemente católica, ao contrário de outras capitais como Recife e Salvador.

As origens da cidade, que tantas e tão acaloradas polêmicas têm gerado entre intelectuais cearenses, desde particularmente os anos 1960, dão testemunho do quanto a religião faz parte da história local. Fortaleza foi fundada por Martim Soares Moreno na Barra do rio Ceará, no litoral Oeste, a partir de um pequeno santuário católico? Ou resulta de povoamento surgido em torno do Forte Schoonenborh, edificado sob as ordens de Matias Beck, o holandês calvinista, a meio caminho entre a Barra do Ceará e o litoral Leste?

Os setores mais ligados à orientação católica nunca viram com bons olhos a primazia holandesa na obra de colonização (Furtado Filho, 2002) e o invasor flamengo teve vetado o seu nome em uma avenida da cidade nos anos 60, embora o Forte - hoje nomeado de Nossa Senhora de Assunção - tenha permanecido como marco de surgimento da cidade. Os "morenistas" Martim Soares Moreno foi posteriormente conquistado pelos flamengos. Assim, uma disputa envolvendo católicos e protestantes já marca Fortaleza desde o seu nascimento e integra o imaginário religioso de sua gente.

No início do século XXI a capital cearense já apresenta transformações que, iniciadas na década anterior, têm feito surgir uma nova Fortaleza. Jovens universitários comparecem às aulas de camisetas e bonés ilustrados por imagens ou frases alusivos ao cristianismo, se organizam em projetos exclusivamente religiosos como - Universidades Renovadas e Profissionais do Reino - que reúnem estudantes para louvores e orações no campus e promovem Calouradas Cristãs e missas em recintos acadêmicos. Um número

\footnotetext{
${ }^{10}$ No modelo ternário há forte presença de católicos no município central, redução na periferia próxima e aumento em direção à periferia mais distante. $O$ modelo binário implica em menores percentuais de católicos no centro e maiores na periferia, conforme o Atlas da Filiação Religiosa e Indicadores Sociais no Brasil (orgs. César R Jacob et alli), Rio de Janeiro, PUC/Loyola/CNBB, 2003.

"Entre os "morenistas" destaca-se o historiador católico Ismael Pordeus, que polemizou principalmente com o "beckista" também historiador Raimundo Girão, e o fez sempre com base em escritos de autores consagrados da história cearense, como é o caso de Capistrano de Abreu.
} 
crescente de automóveis, motocicletas e até bicicletas ostenta símbolos e declarações religiosas. $\bigcirc$ "carnaval da fém,12, os shows de massa reunindo milhares de fiéis para orações e louvor em estádios esportivos e palcos para shows musicais à beira mar, as Caminhadas com Maria, as Marchas para Jesus, a construção de imagens em praças públicas e de capelas nos shoppings, as reuniões de oração e louvor nas avenidas costeiras e em praças são alguns exemplos.

Além das imagens de Maria que "invadem" a cidade, novos cultos a ela são criados nos bairros periféricos. Os mais importantes são a Campanha da Mãe Peregrina de Schoenstatt e o Terço dos Homens, que tem feito aumentar o contingente masculino nas igrejas. Campanhas políticas são respaldadas na pertença religiosa dos candidatos e integram - até de forma exclusiva - eventos de reza do terço em emissoras de rádio e em locais públicos da cidade. Santuários são edificados na capital e no interior e, recentemente, o governador inaugurou a primeira de cinco estações de apoio aos devotos de São Francisco de Assis que demandam, em romaria já tradicional, o Santuário localizado na cidade de Canindé. Busca-se, dizem, incrementar o turismo religioso no Estado.

Na capital cearense, como no restante do país, há entre os católicos diferentes modos de crer e de praticar, expressos principalmente pela cultura religiosa pós Concílio Vaticano II que deu origem ao cristianismo de libertação e à Renovação Carismática, se quisermos identificar somente os dois principais movimentos que se constituíram numa dialética de aproximação e distanciamento com os chamados catolicismo oficial e popular. Em cada um deles há lugares e iniciativas do laicato com um perfil próprio assim como distintas formas de organização e de reelaborações litúrgicas. São diferentes as ênfases e o uso de textos bíblicos, os cultos e imagens preferenciais, a organização comunitária, as representações da religião e da sociedade, além das relações com a hierarquia. A cidade registra, consequentemente, uma presença aguerrida e competitiva das denominações pentecostais em busca de igual visibilidade no espaço público ${ }^{13}$.

\footnotetext{
${ }^{12}$ Chamado HALLELUYA essa festa é uma paródia católica do carnaval e é realizada pela Comunidade Shalom no mesmo período daquele.

${ }^{13}$ Neste texto faz-se uma distinção entre "espaço público" (equivalente a esfera pública) como o âmbito da vida social em que é possível acompanhar a participação dos grupos sociais na produção e circulação de informações, nos debates a elas concernentes e nas decisões que a partir delas são tomadas e "espaço urbano" como aquele fisicamente determinado administrativa e urbanisticamente.
} 
Esse "reavivamento" do catolicismo no Ceará parece-me particularmente significativo (Miranda, 2010) pois, a despeito da propalada adesão de sua população ao catolicismo, vale aqui, para os praticantes desse credo, a mesma observação feita para o restante do Brasil no último censo, a saber: numericamente eles aumentam, mas esse aumento é inferior ao crescimento da população. Logo, a tradição católica perde fiéis também no Ceará. Pode-se inferir, como hipótese, que essa maior visibilidade observada, essa presença renovada no espaço público, está ligada a um processo de conversão interna ao catolicismo (Hervieu-Léger; 2005). Trata-se, pois, de um tipo especial de "convertido", surgido de um contexto intra e extra eclesial particular.

Em Fortaleza a Renovação Carismática e suas comunidades servem de referência para o país. Pode-se afirmar que o catolicismo dos cearenses é plural se observamos as distintas formas de concebê-lo e praticá-lo e se o comparamos ao que era no início da República. E é esse catolicismo fragmentado e "renascido" que busca formas de convivência interna e externa que parece estar à frente do aludido processo de reconfiguração do espaço urbano aqui considerado.

Até finais de 1970 e início de 1980 as práticas dos fiéis e a possibilidade que ofereciam para a visualização da presença católica no espaço da cidade eram reportadas às paróquias, hoje em número de 52 [e 9 áreas pastorais] ${ }^{14}$, concentravam-se quase exclusivamente nos templos e seguiam a orientação de clérigos e religiosos (e do bispo em última instância). Tal era e continua a ser o caso das pastorais ${ }^{15}$. Essas pastorais não têm sede, sendo a Arquidiocese sua referência em termos de localização, quando não as dependências das igrejas, sob a influência dos párocos. Ao longo de toda a segunda metade do século $\mathrm{XX}$, novas formas de pensar a condição cristã e novos documentos papais ${ }^{16}$ vão ampliando o

${ }^{14}$ Dados fornecidos pela secretaria da Arquidiocese à bolsista Emília Morais. Em Fortaleza, algumas comunidades ou bairros que já possuem certa estabilidade financeira e um número de lideranças considerável e fixo que possam assumir a "independência" para formar uma nova paróquia pedem autorização à Arquidiocese. A Cúria diocesana é responsável pela liberação e "nomeação" de uma comunidade como paróquia. $O$ padre é responsável por sua paróquia, geralmente a Igreja Matriz, e também pelas comunidades circunvizinhas, portanto celebram nas capelinhas menores dos rincões do bairro.

15 Apresentadas como os "carismas da Igreja", as pastorais caracterizam trabalho de cada paróquia, mas devem manter a mesma forma de atuação. Para isso, existem as Coordenações de Pastoral na Arquidiocese, que orientam as demais igrejas através de formações para que trabalhem em unidade.Um critério importante para o reconhecimento de uma comunidade como paróquia é a existência de um movimento pastoral sólido, principalmente no trabalho das Pastorais Sacramentais: Batismo, Eucaristia, Catequese e Dízimo.

${ }^{16}$ Alguns grandes teólogos europeus prepararam essa "abertura", trazendo à luz textos de certa forma revolucionários, como é o caso do dominicano francês Yves Congar e de seu livro Jalons pour une théologie 
espaço das iniciativas laicas dentro da instituição assim como criando condições para certa "inventividade" por parte dos fiéis.

A capital seguiu majoritariamente fiel ao chamado catolicismo oficial, identificado com as diretrizes diretamente emanadas do Vaticano. Isso até que, no final dos anos 1970 - coincidindo, pois com o auge do cristianismo de libertação - aqui chegasse a Renovação Carismática. Reunindo, ao contrário daquele, segmentos de classe média urbana, a RCC, e sua proposta de religiosidade voltada para a oração e o louvor, foi conquistando espaço entre os católicos fortalezenses.

Alguns autores dão conta do processo de reabsorção pela Igreja Católica dessas novas iniciativas que de certa forma deixavam à margem os seus sacerdotes e demais representantes ordenados ${ }^{17}$. Em Fortaleza a RCC esteve, desde o início, muito próxima das diretrizes romanas. Para isso contribuiu a aproximação de Moisés Azevedo, fundador da Comunidade Shalom, com o Papa João Paulo II, durante visita a Fortaleza, através do então Arcebispo Dom Aloisio Lorsheider. As comunidades carismáticas são autônomas, não pertencem à Arquidiocese como acontece com as pastorais. A Comunidade Shalom conseguiu a aprovação de seus estatutos e tornou-se um Movimento de Direito Pontifício cuja obediência é ao Papa. Assim, nem todas as comunidades são iguais e igualmente relacionadas com a Arquidiocese.

Hoje a Comunidade Shalom não somente consagra laicos como passou a ordenar padres com o "seu carisma"18. Outro elemento a ser considerado quando se observa o capital simbólico que vem sendo acumulado pela Shalom é o investimento maciço de suas lideranças na candidatura de membros consagrados (Miranda, 2015). Em 2014 foi eleito um deputado estadual e nas eleições deste ano de 2016 um vereador. Entende-se aqui que o grande movimento laico representado pela Renovação Carismática Católica é o principal

du laícat. Em 1964, a Constituição Dogmática Lumen Gentium, transforma-se na referência para os católicos, quando o assunto é o "apostolado leigo", que deixa de ser visto pela cúpula eclesial apenas como "participação", "cooperação" ou "colaboração" no apostolado hierárquico, como ocorria desde o papado de Pio XI. Em seguida, a Constituição Gaudium et Spes, traça-lhe as linhas da ação pastoral.

${ }^{17}$ Em relação ao catolicismo francês leia-se Hervieu-Léger (1990) e, no caso do catolicismo no Québec, Côté e Zylberberg (1990)

${ }^{18} \mathrm{O}$ padre Antonio Furtado, primeiro sacerdote ordenado na Comunidade Shalom, em dezembro de 2004, é hoje uma de suas lideranças carismáticas mais festejadas. Seu programa na Rádio Shalom tem altíssima audiência, com interação com os ouvintes através de ligações ou mesmo presença física nos studios da Rádio. Através desse programa, o Pe. Antônio Furtado tem levado multidões para os eventos prestigiados pela Rádio, como a Festa dos Arcanjos. A missa que ele celebra na sede pioneira da Shalom traz fiéis de todos os recantos da cidade para o elitista bairro Meireles. 
responsável pela revigorada presença pública do catolicismo contemporâneo e por um novo tipo de "consumo" do espaço urbano em Fortaleza. Mesmo quando não são originados em seus grupos ou comunidades alguns dos novos cultos urbanos rapidamente Ihe seguem os passos quanto à ênfase na oração e no louvor.

A Campanha da Mãe Rainha e Vencedora Três Vezes Admirável de Schoenstatt lou simplesmente Campanha da Mãe Rainha) tem sua base no bairro Conjunto Nova Assunção, no litoral Oeste da cidade e o Terço dos Homens, embora com adeptos também naquele mesmo bairro, tem sua maior e mais visível expressão sediada pela igreja de Nossa Senhora de Fátima, no bairro de mesmo nome. Pode-se dizer que esses são bairros com perfil sócio-econômico e nível de escolaridade de seus habitantes significativamente diferentes. São também igualmente representativos do catolicismo fervoroso que está mudando a face da cidade. Finalmente, pela sua localização, esses dois cultos - que guardam relação entre si - mostram o deslocamento das práticas católicas mais significativas do antigo eixo catedral/centro/Fátima de modo a incluir nesse circuito a zona limite da faixa litorânea Oeste. E já é possível verificar também iniciativas que tornam públicas novas devoções e festas nas paróquias de N.Sa. da Saúde e de N.Sa. de Lourdes (esta de culto bem recente), no litoral Leste da cidade. Ao olhar mais atento vaise expandindo o espaço urbano de demarcação católica, mesmo sem a construção de novas igrejas, o que se constitui uma característica da atualidade em Fortaleza.

O bairro de Fátima, equidistante do centro e dos primeiros bairros "chiques" da zona Leste, tradicionalmente residencial, fazendo limite com aquele que abriga o campus originário e a Reitoria da Universidade Federal do Ceará, é um bairro caracterizado como de classe média. A boa localização e a grande quantidade de serviços disponíveis o torna disputado para moradia. A igreja de Nossa Senhora de Fátima hoje chamada de Santuário ${ }^{19}$, tem sido uma referência para o culto mariano em todo o Estado e, nos últimos anos, a

\footnotetext{
${ }^{19}$ A igreja de Fátima foi inaugurada em 1955. Esse "reavivamento do catolicismo" no Ceará tem como outra característica a construção de novos "santuários" como o de Nossa Senhora Imaculada Rainha do Sertão, estrura grandiosa edificada na cidade de Quixadá, na região central, inaugurada em 1995 (onde já existem umarádio e uma faculdade católicas) e que tem instituído novas celebrações e romarias. Ao tempo em que este artigo é redigido, desenvolve-se uma campanha de arrecadação de fundos para a construção, emFortaleza, de uma igreja doSantíssimo Sacramento, para adoração perpétua pelos fiéis. O objetivo é transformá-la em "ponto de peregrinação" segundo um dos dirigentes do Condomínio Espiritual Uirapuru CEU - construído a partir de 2000. Ele reúne mais de uma dezena de entidades de assistência, todas religiosas, "com diferentes carismas e variados públicos-alvo".
} 
cada dia 13 do mês missas são rezadas durante todo o dia e uma procissão é realizada entre a igreja do Carmo, no centro, e a igreja de Fátima. $\bigcirc$ ponto alto do culto são as celebrações do dia 13 de maio, data da primeira das supostas aparições da Virgem a três pastores portugueses em Fátima em 1917.

No outro lado da cidade está localizado o também hoje chamado de Santuário de Nossa Senhora de Assunção, sede do Culto à Mãe Rainha e agora outro grande polo aglutinador de fiéis. A Campanha é realizada desde 2003 no Santuário do Conjunto Nova Assunção e em 2007 uma imagem de 12 metros foi construída no espaço público em frente ao templo, para "fortalecer a comunidade e chamar a atenção para o santuário"20. ○ novo culto une moradores em grupos de oração, louvor e evangelização. $\bigcirc$ Conjunto Nova Assunção viu seus limites territoriais grandemente alargados com a participação de habitantes de bairros vizinhos nas atividades dirigidas por laicos de todas as idades. A comunidade originária se multiplicou e o Santuário entrou como elemento importante no circuito ampliado de eventos católicos que interliga hoje a cidade de Leste a Oeste.

Mas o Terço dos Homens é também ali um movimento muito forte. $\bigcirc$ bairro é o Vila Velha (ou Barra do Ceará), com predominância de residências e pequenos comércios. Conforme o IBGE é o quinto mais populoso da capital. É um bairro pobre e com problemas de violência urbana formado por conjuntos residenciais entre os quais o Nova Assunção, onde, em 1983, em regime de mutirão com a participação maciça dos moradores, foi iniciada a construção do Santuário. O pároco, padre Sales, afirma que à paróquia estão vinculadas seis comunidades religiosas e quatro capelas ${ }^{21}$. Além do nome da padroeira de Fortaleza, a igreja de Nossa Senhora da Assunção ganhou grande visibilidade no cenário religioso católico da cidade por causa da Caminhada com Maria e da enorme imagem da Virgem que foi erigida nas suas imediações ${ }^{22}$. Bem recentemente começamos a

\footnotetext{
${ }^{20}$ Conforme depoimento de uma liderança laica a Aurimar Rocha em 2009.

${ }^{21}$ Entrevista a Aurimar Albuquerque em 25/03/2009

${ }^{22}$ A Campanha da Mãe Rainha teve origem na Alemanha durante a primeira Guerra Mundial e chegou ao Brasil em 1979. Em Fortaleza ela começou "clandestinamente"22, fora da ingerência eclesial, como iniciativa eminentemente laica posteriormente "encampada" pela Igreja Católica. A santa é três vezes admirável "como mãe de deus, do redentor e dos redimidos". Tem uma imagem característica que é objeto do culto e só em Santa Maria, no Rio Grande do Sul, são fabricados esses ícones marianos. A reza do terço está no centro da devoção cuja base são as famílias. Inicialmente organizadas em 30, elas se revezam na atividade de "zelo" e programação da vilegiatura da imagem que, durante um mês, "visita" cada dia uma residência onde todos se reúnem para rezar o terço e louvá-la. A santa permanece 24 horas em cada casa de cada membro dos grupos. Há uma estrutura laica de "missionários" e "zeladas", cujas atividades são referidas ao pároco.
} 
ouvir relatos de "visitas" da santa a residências de classe média também no lado Leste da cidade, com o que estaria "fechado o circuito" ou "coberta" toda a extensão do litoral de Oeste a Leste.

O Terço dos Homens começou a ganhar adeptos e a se replicar nas demais paróquias quando foi implantado na igreja de Fátima, na primeira metade dos anos 2000. Hoje, sempre nas segundas-feiras, nunca menos de 300 pessoas comparecem ao culto que, nas palavras do vice-coordenador, "está resgatando os homens para a igreja"23.

Num processo que historicamente vem da Antiguidade à modernidade passando pela Idade Média o logradouro que hoje chamamos praça pública tem representado a sociabilidade, o prazer de estar com o outro, que estabelece em definitivo a diferença urbana, a urbanidade. $\bigcirc$ campo não oferecia isso. Nesse percurso a praça se "secularizou" tornando-se lugar de sociabilidades que não incluem as práticas religiosas cotidianas cujo espaço específico em princípio é o templo. Na Fortaleza da virada de século XX para XXI uma nova dinâmica parece apontar no sentido contrário ou seja, as praças públicas vão lentamente se tornando lugares de culto, reinvestindo o caráter religioso. E são as praças outro dos elementos centrais desse processo de reconfiguração urbana de Fortaleza pelas práticas católicas. Melhor dizendo, os usos religiosos das praças.

Em Fortaleza e na sua Região Metropolitana destacam-se, entre muitas outras menores ou menos visíveis, as seguintes imagens de santos em logradouros públicos: Jesus Cristo (av. José Bastos em Fortaleza); Menino Jesus de Praga (Chorozinho); Nossa Senhora Aparecida (Montese, Fortaleza); Nossa Senhora de Fátima (Praça Pio IX ou de Fátima, Fortaleza); Nossa Senhora das Graças (Oficina Cordeiro, na Aerolândia, Fortaleza); Nossa Senhora das Graças (Lago Jacareí, Fortaleza); Nossa Senhora de Fátima (pracinha da Coelce, Fortaleza); Nossa Senhora da Assunção (Conjunto Nova Assunção, Fortaleza); Nossa Senhora da Saúde (Praça Nossa Senhora da Saúde, Fortaleza); Padre Cícero (Anel Viário, Maracanaú); Santa Edwiges (Av. Leste-Oeste, Fortaleza); Santa Edwiges (Caucaia); São José (praça da Igreja Matriz, Maracanaú); São Judas Tadeu (Conjunto Timbó, Maracanaú) e São João (Horizonte). Destas, a totalidade das imagens de Maria está localizada na capital e sua construção data das últimas duas décadas.

\footnotetext{
${ }^{23}$ Entrevista concedida ao aluno Aurimar Albuquerque em 06/03/2009.
}

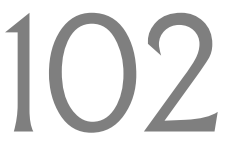

Numen: revista de estudos e pesquisa da religião, Juiz de Fora, v.19 n.2, 2016, p. 86-110. 
Esse é um fenômeno muito recente e tem gerado polêmicas que se explicitam nas Casas Legislativas ${ }^{24}$, na mídia ${ }^{25}$ e nas conversas com os usuários católicos da praça, com os que professam credos não católicos e com os não religiosos ${ }^{26}$. A primeira imagem a mobilizar a opinião pública da capital foi a de Nossa Senhora de Fátima, na praça Pio IX (também chamada de Fátima), do outro lado do Santuário, na Avenida Treze de Maio. Com 13 metros de altura e de estética bastante controversa ela foi inaugurada em 2008. Segundo noticiou o jornal Diário do Nordeste no dia 22 de janeiro de 2008 a colocação da imagem foi de iniciativa do então vereador Walter Cavalcante que é ligado ao movimento Encontro de Casais com Cristo (RCC), com anuência da Prefeitura de Fortaleza e do pároco da igreja.

Com a construção da imagem a praça vem registrando mudanças nas formas de uso pelos moradores do bairro ${ }^{27}$. Durante dois meses membros da equipe de pesquisa a observaram em horários diferentes, conversando com seus frequentadores que além de habitarem a região, são em sua maioria católicos. Eles defendem veementemente a existência da imagem por muitos já transformada em lugar de culto. Os não adeptos dessa transformação no uso do logradouro, mesmo católicos, destacam que a iniciativa de colocar a santa na praça tem motivações políticas: beneficia a administração municipal e traz bônus para a igreja. A consequência mais apontada por todos é o fato de que a praça vem se tornando de uso exclusivo dos católicos. Há três anos a praça que antes não trazia nenhuma identificação religiosa passou a ser definida como "a praça da imagem de Nossa Senhora". Eudes, que há dez anos mora nas ruas da vizinhança, chama o ícone de "estátua capitalista" e critica sua finalidade política. Mas afirma beneficiar-se da presença da imagem o que, segundo diz, torna as pessoas mais generosas na doação de esmolas. Ele presencia várias formas de culto, com o uso de velas, flores e até ex-votos que encontrou aos pés da santa e vendeu no centro da cidade para comprar comida.

\footnotetext{
${ }^{24}$ A Assembléia Legislativa e a Câmara Municipal têm abrigado calorosos debates entre apoiadores e críticos dessa construção indiscriminada de imagens sacras na cidade. Entre os últimos estão os evangélicos e os ateus.

${ }^{25}$ Os jornais de Fortaleza têm publicado reportagens e artigos sobre as imagens de santos, onde se destacam elementos que questionam sua pertinência num Estado oficialmente laico como o brasileiro, que as vinculam a interesses eleitorais de candidatos católicos militantes ou que aludem ao aspecto estético, considerando-as de gosto no mínimo duvidoso.

${ }^{26}$ Também a população ouvida nas ruas e demais locais públicos se divide sobre o assunto.

${ }^{27} \mathrm{Em}$ outras praças, como é o caso de uma nas proximidades da Lagoa da Parangaba, o pároco sai da igreja para fazer celebrações na praça onde foi edificada uma imagem.
}

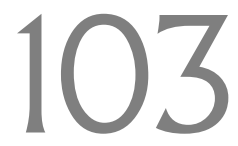

Numen: revista de estudos e pesquisa da religião, Juiz de Fora, v.19 n.2, 2016, p. 86-110. 
Os católicos entrevistados mostraram-se favoráveis à presença do ícone e o vêm como "respeito à religião", embora mais de uma pessoa tenha se mostrado totalmente contra a presença de símbolos de outros tradições. Alguns consideram que a imagem atraiu mais pessoas e trouxe mais policiamento para a área. Um morador que há muito não visitava a praça afirma que "as pessoas estão voltando a passear no lugar depois da reforma e da colocação da estátua".

No último ano, vem chamando atenção também a Praça do Cristo Redentor onde foi erigido um humilde oratório que reúne católicos - em sua maioria mulheres - com suas cadeiras de plástico, no início das noites de quarta-feira, ao lado de uma caixa metálica do sistema de telefonia que, como várias na cidade, foram grafitadas por Narcélio Grude, um artista local. Os fiéis rezam e cantam apesar do trânsito infernal, do movimento do posto de gasolina, do ponto de motoristas de táxis, da presença da polícia, das pessoas que passam para se divertir no Centro Cultural Dragão do Mar, de crianças que se drogam e de pedintes. Na Avenida Beira Mar, local de prática de esportes, de restaurantes, bares e comércio artesanal hoje, principalmente ao cair da tarde, é possível observar grupos que se reúnem para orações e louvor em torno de uma imagem que é levada pelos integrantes do grupo a cada nova reunião. Esses são apenas alguns dos casos mais relevantes.

Essas imagens desrespeitam a natureza laica do estado brasileiro; são feias e comprometem esteticamente a paisagem urbana; oferecem novas possibilidades de culto; protegem a cidade e seus habitantes; reforçam a vocação religiosa do povo fortalezense; justificam a construção de ícones alusivos a outros credos religiosos. Essas são constatações dos pesquisadores com base nas muitas argumentações "pro" e "contra" essa "invasão de imagens" nas ruas e praças de Fortaleza ouvidas ao longo do trabalho de campo. Como se pode notar são posicionamentos que implicam "olhares" distintos. Ora religiosamente informados, ora preocupados com o respeito aos valores republicanos, ora atentos à estetização do espaço urbano. Nesse último caso elas ajudam a pensar como foram produzidas e constituídas como tal as obras consideradas dignas do olhar estético e quais são as condições nas quais se produziu e se reproduz continuamente no decorrer do tempo a disposição estética que exigem.

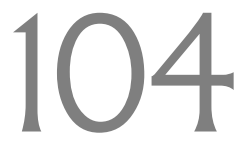


No entanto, conforme já explicitado, esse não é o interesse deste artigo, voltado para o "olhar" religiosamente informado. Sim, porque é ele que justifica e legitima o que parece absurdo ao homem e à mulher sem religião ou ao fiel que não aprova essa transformação nos usos sociais das ruas e praças, para não falar dos evangélicos sempre avessos às reproduções imagéticas.

\section{Sociabilidades (re)inventadas}

A presença crescente de imagens sacras e os novos usos dos locais públicos que elas estimulam não são elementos isolados, por exemplo, da força que veem ganhando em Fortaleza as caminhadas. As implicações dessa "cartografia da fé" em Fortaleza se estendem para além da interpelação da laicidade. Senão vejamos.

Essas procissões são permanentemente transformadas. A explicação para isso parece dever ser buscada internamente, como na já aludida autonomização do laicato que acompanha as transformações na divisão do trabalho religioso, mas não se pode esquecer também a concorrência entre denominações religiosas, o desenvolvimento das modernas tecnologias de comunicação e as exigências de uma sociedade mercantilizada, entre os outros elementos explicativos.

A Caminhada com Maria, tradicionalmente chamada de procissão da padroeira ou de Nossa Senhora da Assunção, até os anos 1980 ligava a Catedral localizada ao lado do Forte hoje também chamado de Nossa Senhora da Assunção à igreja de Nossa Senhora do Carmo, ambas no centro. $O$ cortejo seguia pelas ruas centrais e quando muito ia até o Seminário da Prainha, nos limites com a Praia de Iracema. Em 2002, o dia 15 de agosto, agora no rol dos feriados municipais, a procissão virou Caminhada com Maria e liga, conforme já assinalado, o centro ao extremo Oeste da cidade, onde está situado o Santuário. Na véspera da festa uma Moto caminhada com Maria leva a imagem da santa até a Barra do Ceará, de onde virá acompanhada pelos fiéis na Caminhada do dia 15. Expandiu-se o itinerário, multiplicou-se o evento e católicos, carismáticos ou não, se fazem cada vez mais presentes. A administração pública garante a fluidez do trânsito, o acesso dos fiéis e a segurança dos participantes. Um comércio ambulante e desordenado prolifera nesses dias ao longo de todo o percurso. O mesmo comércio temporário que 
compromete calçadas e ruas, complicando o trânsito em frente à igreja de Fátima a cada dia 13 do mês e, particularmente no dia 13 de maio. São imagens, terços, camisetas da santa, comidas, bebidas e até adereços. Esse tipo de comércio hoje toma conta de Fortaleza e há os ambulantes que se deslocam entre eventos em vários pontos da cidade.

A essa exibição de devoção católica os evangélicos respondem com a Marcha para Jesus, cortejo que reúne, anualmente em Fortaleza todas as denominações reformadas históricas. O itinerário dessa feita é outro, mas não se afasta do eixo centro/litoral. Não poucas são as polêmicas entre fiéis das duas tradições pois os evangélicos acusam o poder público de empenhar-se mais nas garantias à realização dos eventos católicos. $\bigcirc$ que se observa é que embora as iniciativas partam de católicos e de protestantes as duas marchas reúnem cada vez mais um número crescente de cristãos que não as vêem como mutuamente excludentes. Também esse é o caso quando dos shows de massa de artistas de ambos os credos nas areias do palco montado para esse tipo de evento na Praia de Iracema. $\bigcirc$ caráter gratuito desses shows Ihes garante sempre um público de milhares de fortalezenses.

Dona Madalena Brito, moradora do Conjunto Nova Assunção diz que a Campanha da Mãe Rainha trouxe grandes e boas mudanças para sua vida. Antes de começar a participar ela quase não tinha amigas, conhecia pouco o bairro e não se deslocava muito por suas ruas. Hoje conhece muita gente, circula com prazer pela vizinhança e aumentou o círculo de amigas. "Aproximou-se mais de Maria, da igreja e das pessoas". Tem mais "alegria de viver". Com poucas variações esse é o teor dos depoimentos entre as moradoras do local. Já maiores de 60 anos - algumas com mais de 80 - essas mulheres e os jovens são os grandes responsáveis pelo culto e pelas mudanças na comunidade. Eles atraídos pela música e pela festa e elas por uma nova sociabilidade, de partilhas e solidariedade. Vizinhas distantes viram comadres e passam a festejar os aniversários umas das outras. Cada uma delas, ao receber a visita mensal da santa, reúne os amigos e a família em torno de lanches, reza do terço e louvores. Elas trocam confidências, conselhos, pedem ajuda e organizam trabalhos voluntários de assistência à comunidade. Para Dona Amélia o culto é responsável por "um grupo unido, solidário e participativo". Os homens são raros na Campanha da Mãe Rainha mas engrossam as hostes do Terço dos Homens tanto no Santuário de Nossa Senhora da Assunção quanto na igreja de Fátima. Inúmeros 
deles afirmam que gostam de frequentar a igreja sem as mulheres e alguns atribuem à "timidez masculina" o êxito dessa prática segmentada. Pode-se observar uma participação entusiasmada no ritual do $\operatorname{Terço}^{28}$, assim como comportamentos descontraídos, abraços calorosos, uso de camisetas do movimento e partilha de êxitos e problemas pessoais.

Os participantes do Terço dos Homens no Conjunto Nossa Senhora da Assunção instituíram o Terço em sua casa e a Bolsa de Empregos. Esta última funciona assim: antes da celebração o participante informa o coordenador sobre uma vaga de emprego que deseja divulgar. Ao final, antes da benção ele vai à frente e fala do emprego e dos requisitos. Em cada reunião aparece uma média de três vagas. Dessa forma, "nos sentimos unidos e podemos nos ajudar" diz o Sr. Ernani. Há interações outras que ocorrem fora dos lugares de culto. Na paróquia de Nossa Senhora de Fátima existem as viagens. Um dos membros é proprietário de uma agencia de viagens e organiza passeios a locais de forte apelo religioso como a Santuário de Aparecida e a cidade-teatro de Nova Jerusalém, em Pernambuco. Ali também todos enfatizam as novas amizades e o quanto elas estendem os contatos até espaços fora do lugar de culto.

Na praça da imagem de Nossa Senhora de Fátima encontramos Manoel que ali vem todo dia para ouvir rádio. Senta-se sempre no mesmo banco em frente à igreja. Na sua opinião mais pessoas deveriam vir "adorar" a imagem pois ela é muito bonita. Ele não esconde a indignação com "um povo da Universal"29 que passou pela praça e disse "isso é pra enganar os bestas" (referindo-se a Nossa Senhora).Fátima e a amiga turista católica aproveitavam para fazer fotos.

É importante destacar a construção de laços cada vez mais fortes entre duas atividades até bem pouco tempo tidas como inconciliáveis: o lazer e a devoção religiosa. Há alguns anos o jornal $\bigcirc$ Povo publicou uma pesquisa sobre lazer na cidade de Fortaleza que curiosamente mostrava, entre as formas de divertimento mais procuradas, em primeiro lugar a ida à praia logo seguida pela ida à igreja. Vale lembrar que igreja aqui se

\footnotetext{
28 O ritual do Terço dos Homens, ao qual os fiéis comparecem todos portando seus terços e vestindo a camisa identificatória, compreende a efusiva acolhida de novatos e muita música. A imagem da Mãe Rainha é tocada pelos participantes antes de iniciada a reza ganha reverências durante toda a celebração. Os testemunhos feitos não diante de todos mas em pequenos grupos ou para o coordenador dão conta de mudanças benéficas na vida dos fiéis que aderiram ao movimento. $A$ frequência ao culto vem aumentando também a frequência às missas.

${ }^{29}$ Alusão aos fiéis da Igreja Universal do Reino de Deus
} 
refere amplamente aos templos de todas as denominações cristãs da cidade. $\bigcirc$ trabalho de campo que serve de base a estas reflexões atesta que os templos, comunidades e demais lugares utilizados de forma temporária ou definitiva para a prática religiosa vêm se transformando em espaços de uma sociabilidade que extrapola a oração e o louvor e sem deixar de tê-los como centrais, cria laços, institui solidariedades, e oferece alternativas seguras e de baixíssimo custo às programações "laicas". Não se pode esquecer que elas incluem esporte, música, dança, espetáculo e disponibilizam transmissões midiáticas as mais diversificadas $^{30}$. Os megaeventos como Queremos Deus e Halleluya, promovidos pela Comunidade Carismática Shalom já fazem parte do circuito católico regional e trazem a Fortaleza turistas religiosos de dentro e fora do Estado. Nestes casos há benefícios econômicos para a indústria hoteleira e de restauração.

\section{Como conclusões}

traçado de uma cartografia da fé pelos usos religiosos do espaço urbano em Fortaleza é o que se quis mostrar. Esse "mapa invisível" da cidade é consequência não intencional das novas formas de praticar a cidade pelos sujeitos religiosos católicos que a habitam. Os fatos aqui relatados e nos quais se apoia esta reflexão não resultam de uma ação programada por parte da administração pública, de qualquer instituição religiosa ou de grupos de fiéis. No entanto os elementos que criam suas condições de possibilidade reúnem tanto as recomposições do catolicismo brasileiro, que entre outras coisas deu maior liberdade ao segmento laico levando-o a uma prática criativa e inventiva, quanto as particularidades da cultura católica local. Acrescente-se ainda a notória falta de planejamento urbano na capital cearense ${ }^{31}$, cidade cujas edificações estão longe de obedecer um código de posturas que Ihe confira um rosto, uma identidade do ponto de vista do ordenamento administrativo.

Conforme já destacado os novos usos religiosos para muitos desrespeitam a natureza laica do estado brasileiro enquanto para outros reforçam a vocação religiosa do

\footnotetext{
30 O Terço dos homens, por exemplo, possui sites e programas de rádio.

${ }^{31}$ Fausto Nilo, arquiteto responsável por vários projetos de intervenção urbana em Fortaleza afirmava em entrevista ao jornal $O$ Povo $[1 / 7 / 2012)$ que são muitos os problemas, por exemplo, para que a capital cearense passe de cidade unicentral a policentrada como as metrópoles desse início de século XXI.
} 
povo fortalezense. Eles garantiriam o pluralismo religioso preconizado na Constituição Federal afirmam, num raciocínio simplista, inúmeros fortalezenses católicos e evangélicos. A polêmica está assim instalada como outra consequência não programada dessas novas práticas. Ela chega à agenda política e alimenta os debates acadêmicos sobre laicismo e tolerância religiosa além daqueles sobre a reinvenção das sociabilidades urbanas. Esses usos religiosos efêmeros e permanentes do espaço urbano por sua vez não contradizem a tese compartilhada pelos cientistas sociais interessados nos fatos religiosos, de que se vive um processo acentuado de desinstitucionalização das práticas $^{32}$ e de privatização do público pelos grupos religiosos, ao contrário, eles os explicitam. Essas práticas são como tantas outras igualmente religiosas objeto da crescente espetacularização que marca a cultura urbana e nela deixam suas marcas. É o caso, por exemplo, dos frequentes testemunhos de fé oferecidos em eventos sociais privados (como casamentos e aniversários), sepultamentos e mesmo em cerimônias acadêmicas ${ }^{33}$. Esses também são significativos aspectos a serem analisados pelos interessados nas dinâmicas particulares das práticas de individualização e privatização da religião em sociedades distintas.

As imagens "estão saindo das igrejas e indo pras ruas" como disse em tom desaprovador um pastor presbiteriano. Eu lembro que elas trazem junto as celebrações e as orações. $\bigcirc$ que mais virá nessa trilha de "reencantamento"?

É certamente cedo para ir além da constatação das mudanças, da busca dos múltiplos elementos que as explicam e das velhas e novas questões que provocam. E isso já é suficiente: Elas "são boas para pensar".

32 O censo de 2010 mostra inclusive o crescimento de evangélicos sem pertença eclesial.

33 Tive a oportunidade de assistir, numa defesa de dissertação de mestrado em Geografia na UFC, à realização de um ato de louvor e bênção celebrado por um pastor evangélico (pai do aluno), na sala mesma onde acabava de ter lugar o ritual acadêmico. 


\section{Referências Bibliográficas}

BARREIRA, Irlys; MATTOS, Geísa. Subversões do olhar: evidências temporais de uma microssociologia dos espaços urbanos. In: Caderno $C R H$, v. 26, no. 69, set/dez, pp. 529544, 2003.

BÉRAUD, Céline; PORTIER, Philippe. Métamorphoses catholiques. Paris: Éditions de la Maison des Sciences de l'Homme, 2015.

BOURDIEU, P. A economia das trocas simbólicas, São Paulo: Perspectiva, 2003. . La distinction. Paris: Minuit 1979.

CANCLINI, Nestor G. Imaginários culturais da cidade: conhecimento/espetáculo/desconhecimento. In: Coelho Teixeira (org.) A cultura pela cidade, São Paulo: lluminuras, pp. 15-31, 2008.

CASANOVA, José. Public religion in the Modern World. Chicago : The University of Chicago Press, 1994

- Reconsiderar la secularización : una perspectiva comparada mundial. In : Revista Académica de Relaciones Internacionales, no. 7, noviembre, UAM-AEDRI, 2007. . The Secular and Secularisms. In : Social Research, vol.76, no. 4, 2009. CENSO IBGE 2010. www.censo2010.ibge.gov.br

CHARTIER, R. A ordem dos livros. Brasília: Ed. UnB, 1999.

. Pouvoir et cultures. In: Cahiers de Recherche no. 11, Lyon: Université Lumière Lyon, 1993.

. Textes, performances, publics. In: Cahiers de Recherche no. 16, Lyon: Université Lumière Lyon, 1995.

. Formas e sentido: cultura escrita entre distinção e apropriação. Campinas: Mercado das Letras, 2003.

CÔTÉ,P. e ZYLBERBERG,J. Univers catholique romain, charisme et individualisme: les tribulations du renouveau charismatique canadien francophone. In: Sociologie et societies, vol. XXII, no. 2, octobre 1990, Montréal: Presses de I’UM, pp. 81-93, 1990.

DE CERTEAU, M. A invenção do cotidiano, vols. 1 e 2, Petrópolis: Vozes, 1994. DIOTALLEVI, Luca. O sentido e o problema do separatismo moderado: por uma contribuição sociológica à análise da religião no espaço público. In: Debates do NER, Porto Alegre, ano 16, no. 27, jan/jun, pp. 19-48, 2015. 
FURTADO FILHO, J. Soares Moreno e Matias Beck: inventário de uma polêmica nos escritos de Ismael Pordeus, Fortaleza: Museu do Ceará, 2012.

HERVIEU-LÉGER, D. De quelques recompositions culturelles du catholicisme français. In: Sociologie et sociétés, vol. XXII, no. 2, octobre 1990, Montréal: Presses de I'UM, pp. 195203, 1990.

. Le pèlerin et le converti. Paris : Flamarion, 1999.

JACOB, C.R. Atlas da filiação religiosa e indicadores sociais no Brasil, Rio de Janeiro: Ed. PUC/Loyola/CNBB, 2003.

LEFEBVRE, H. O direito à cidade. São Paulo: Centauro, 2008.

LE GOFF, J. Por amor às cidades. São Paulo: UNESP, 1998.

MAFRA, Clara . O que os homens e as mulheres podem fazer com números que fazem coisas. In: TEIXEIRA, F.; MENEZES, R (org) Religiões em Movimento - o censo de 2010, Petrópolis, Vozes, 2013.

MACLURE, Jocelyn; TAYLOR, Charles. Laicité et liberté de conscience. Montréal: Boréal, 2010.

MAGNANI, J.G. De perto e de dentro: notas para uma etnografia urbana. In: Revista Brasileira de Ciências Sociais vol. 17, no. 49, São Paulo: ANPOCS, 2002.

MARIANO, Ricardo. Laicidade à brasileira: católicos, pentecostais e laicos em disputa na esfera pública. In: Civitas (Revista de Ciências Sociais) no.11(2), p.238-258.

MIRANDA Júlia. O poder e a fé. Fortaleza : Edições UFC, 1987.

. Estado laico no Brasil: entre sofismas e ambiguidades. In: Cultura y Religión, Vol.VII/ no.2/ junio-diciembre, p.69-85, 2013.

. Convivendo com o diferente : juventude carismática e tolerância religiosa. In : Religião e Sociedade, vol.30, no. 1, julho, Rio de Janeiro : ISER, p.117-141, 2010. . Católicos carismáticos e as eleições de 2012. In: Revista de Ciências Sociais da Unisinos, vol. 51, no. 2, maio/agosto p. 201-211, 2015.

MONTERO, Paula. Religião, laicidade e secularismo - um debate contemporâneo à luz do caso brasileiro. In: Cultura y Religión, vol.VII/no.2/junio-diciembre, p.13-31, 2013. PORTIER, Philippe. La régulation étatique du croire dans les Pays de l'Europe de l'Ouest. Rio de Janeiro : Universidade Federal de Juiz de Fora, 2011.

STEPAN, Alfred. The multiple secularisms of modern democratic and non-democratic regimes. In : CALHOUN, JUERGENSMEYER ; VAN ANTWERPEN. Rethinking Secularism, Oxford : Oxford University Press, 2011. 
VALE, Alexandre. No escurinho do cinema: cenas de um público implícito. São Paulo: Annablume, 2000. 